\title{
Effect of Different Soil Moisture Regime on the Yield and Yield Components of Onion
}

\author{
R. Sen, A. T. M. A. I. Mondal, S. Brahma and M. S. Khan \\ Soil Science Division, Bangladesh Agricultural Research Institute, \\ Gazipur-1701, Bangladesh
}

\section{Introduction}

Onion (Allium cepa L.) is the main spice crop grown in Bangladesh. It is used in almost all food preparation and is an integral part of Bangladesh diet. ${ }^{1}$ Onion is grown in 35,000 hactre land and its total production is 1.40 lac ton. ${ }^{2}$ It is grown more or less in all the districts of Bangladesh but the average yield is $4.17 \mathrm{t} / \mathrm{ha}^{2}$ which is very low as compared to other developed countries like USA (42 t/ha), Japan (44.7 t/ha) and South Korea (53 t/ha) as reported by Pathak. ${ }^{3}$ The average world production at present is about $15 \mathrm{t} / \mathrm{ha}^{3}$ Among various factors affecting its production, the role of irrigation assumes greater significance. Onion needs frequent irrigation but it does not tolerate water logging condition. Recently the climatological approach has come out to be the most reliable device for scheduling irrigation. The present study was therefore, undertaken to find out optimum irrigation schedule and water requirement of onion.

\section{Materials and Methods}

The field experiment was conducted at Grey Terrace Soil of Gazipur (AEZ-28) during rabi seasons of 1990-2000 and 2000-2001. Five regimes of irrigation (control, 0.50, 0.75, 1.00 and 1.25 IW/CPE ratio with $4 \mathrm{~cm}$ depth of irrigation water at each irrigation) were tried in randomized complete block design (RCBD) with four replications. One common irrigation of $4 \mathrm{~cm}$ depth was given just after transplanting and the subsequent irrigations were timed on the basis of different IW/CPE ratios. The total number of irrigations including a common irrigation, irrigation schedules of control, 0.50, 0.75, 1.00 and 1.25 IW/CPE ratio were $1,3,4,5$ and 6 , in both years respectively. Five week old seedling of line ON-0193 were transplanted on 6th and 1st December, 1999 and 2000, respectively and the crop was harvested on 20th and 12th March, 2000 and 2001, respectively. Unit plot size was $2 \mathrm{~m} \times 1 \mathrm{~m}$. The spacing was 20 $\mathrm{cm}$ between rows and $10 \mathrm{~cm}$ between plants. Uniform dose of $120 \mathrm{~kg} \mathrm{~N} / \mathrm{ha}$ as urea, $90 \mathrm{~kg}$ $\mathrm{P}_{2} \mathrm{O}_{2}$ /ha as TSP, $90 \mathrm{~kg} \mathrm{~K} \mathrm{~K}_{2} \mathrm{O} / \mathrm{ha}$ as MP and 20 $\mathrm{kg} \mathrm{S} / \mathrm{ha}$ as gypsum were applied. Half urea and all other fertilizer were applied as basal and rest of urea was applied at 45 DAT. The water table depth was below $3 \mathrm{~m}$ through out the experimentation. Hence the contribution of ground water was considered to be 
negligible. The total rainfall during cropping season were $6.5 \mathrm{~cm}$ in 2000 and $5.8 \mathrm{~cm}$ in 2001, the bulk of which was received in the March in both year. There was practically no rain during active growth period of the crop in both the year. Five representative plants were harvested from each plot for recording yield attributes of onion.

\section{Results and Discussion}

The yield, yield components and water use efficiency of onion as responded to different soil moisture regime are presented in Table I and Table II. Bulb diameter, bulb length, individual bulb weight and bulb yield/ha increasing upto $1.25 \mathrm{IW} / \mathrm{CPE}$ ratio of soil moisture regime, but data obtained from 1.00 IW/CPE ratio and 1.25 IW/CPE ratio are statistically similar. Maximum bulb diameter (5.96 cm in 2000 and $6.08 \mathrm{~cm}$ in 2001) obtained from 1.25 IW/CPE ratio which was statistically similar with $1.00 \mathrm{IW} / \mathrm{CPE}$ ratio and comparatively higher from all other treatment. Highest bulb length $(5.64 \mathrm{~cm}$ in 2000 and $5.68 \mathrm{~cm}$ in 2001) obtained from $1.25 \mathrm{IW} / \mathrm{CPE}$ ratio which was significantly higher than all other treatment. Maximum individual bulb weight (67.55 g in 2000 and $69.86 \mathrm{~g}$ in 2001) was obtained from 1.25 IW/CPE ratio which was identical with bulb weight derived from 1.00 IW/CPE ratio (58.14 g in 2000 and $60.77 \mathrm{~g}$ in 2001). Both of above two bulb weight were significantly higher than bulb weight of rest three treatments.

Bulb yield/ha increasing significantly with the increase of soil moisture regime upto 1.00 IW/CPE ratio. Bulb yield /ha was highest in 1.25 IW/CPE ratio (16.32 t/ha in 2000 and $16.59 \mathrm{t} /$ ha in 2001) which was identical with $1.00 \mathrm{IW} / \mathrm{CPE}$ ratio (15.08 t/ha in 2000 and $15.36 \mathrm{t} / \mathrm{ha}$ in 2001). Percent increase in bulb yield due to $1.25,1.00,0.75,0.50 \mathrm{IW} / \mathrm{CPE}$

Table I. Effect of different soil moisture regimes on the yield, yield components and water use efficiency of onion during rabi season of 1999-2000

\begin{tabular}{c|c|c|c|c|c|c|c|c}
\hline $\begin{array}{c}\text { Soil moisture } \\
\text { regimes (IW/ } \\
\text { CPE ratio) }\end{array}$ & $\begin{array}{c}\text { No. of } \\
\text { irriga- } \\
\text { tion }\end{array}$ & $\begin{array}{c}\text { Bulb } \\
\text { diameter } \\
(\mathrm{cm})\end{array}$ & $\begin{array}{c}\text { Bulb } \\
\text { length } \\
(\mathrm{cm})\end{array}$ & $\begin{array}{c}\text { Bulb } \\
\text { weight } \\
(\mathrm{g})\end{array}$ & $\begin{array}{c}\text { Bulb } \\
\text { yield } \\
(\mathrm{t} / \mathrm{ha})\end{array}$ & $\begin{array}{c}\text { \% Yield } \\
\text { increase over } \\
\text { control }\end{array}$ & $\begin{array}{c}\text { Total water } \\
\text { applied includ- } \\
\text { ing rainfall }(\mathrm{cm})\end{array}$ & $\begin{array}{c}\text { Water use } \\
\text { efficiency } \\
(\mathrm{kg} / \mathrm{ha} / \mathrm{cm})\end{array}$ \\
\hline Control & 1 & $1.81 \mathrm{~d}$ & $2.13 \mathrm{e}$ & $12.52 \mathrm{~d}$ & $5.48 \mathrm{~d}$ & - & 10.50 & 521.90 \\
0.50 & 2 & $2.47 \mathrm{c}$ & $3.33 \mathrm{~d}$ & $29.49 \mathrm{c}$ & $8.72 \mathrm{c}$ & 59.12 & 18.50 & 471.35 \\
0.75 & 3 & $4.56 \mathrm{~b}$ & $4.45 \mathrm{c}$ & $44.32 \mathrm{~b}$ & $12.06 \mathrm{~b}$ & 120.07 & 22.50 & 536.00 \\
1.00 & 4 & $5.48 \mathrm{a}$ & $5.21 \mathrm{~b}$ & $58.14 \mathrm{a}$ & $15.08 \mathrm{a}$ & 175.18 & 26.50 & 569.06 \\
1.25 & 5 & $5.96 \mathrm{a}$ & $5.64 \mathrm{a}$ & $67.55 \mathrm{a}$ & $16.32 \mathrm{a}$ & 197.81 & 30.50 & 535.06 \\
\hline LSD & - & $* *$ & $* *$ & $* *$ & $* *$ & - & - & - \\
CV(\%) & - & 6.3 & 4.8 & 14.4 & 8.8 & - & - & - \\
\hline
\end{tabular}


Table II. Effect of different soil moisture regimes on the yield, yield components and water use efficiency of onion during rabi season of 2000-2001

\begin{tabular}{c|c|c|c|c|c|c|c|c}
\hline $\begin{array}{c}\text { Soil moisture } \\
\text { regimes (IW/ } \\
\text { CPE ratio) }\end{array}$ & $\begin{array}{c}\text { No. of } \\
\text { irriga- } \\
\text { tion }\end{array}$ & $\begin{array}{c}\text { Bulb } \\
\text { diameter } \\
(\mathrm{cm})\end{array}$ & $\begin{array}{c}\text { Bulb } \\
\text { ength } \\
(\mathrm{cm})\end{array}$ & $\begin{array}{c}\text { Bulb } \\
\text { weight } \\
(\mathrm{g})\end{array}$ & $\begin{array}{c}\text { Bulb } \\
\text { yield } \\
(\mathrm{t} / \mathrm{ha})\end{array}$ & $\begin{array}{c}\text { \% Yield } \\
\text { increase over } \\
\text { control }\end{array}$ & $\begin{array}{c}\text { Total water } \\
\text { applied includ- } \\
\text { ing rainfall }(\mathrm{cm})\end{array}$ & $\begin{array}{c}\text { Water use } \\
\text { efficiency } \\
(\mathrm{kg} / \mathrm{ha} / \mathrm{cm})\end{array}$ \\
\hline Control & 1 & $1.87 \mathrm{~d}$ & $2.16 \mathrm{e}$ & $13.14 \mathrm{~d}$ & $5.67 \mathrm{~d}$ & - & 9.80 & 578.57 \\
0.50 & 2 & $2.51 \mathrm{c}$ & $3.39 \mathrm{~d}$ & $30.55 \mathrm{c}$ & $8.89 \mathrm{c}$ & 59.79 & 17.80 & 499.44 \\
0.75 & 3 & $4.65 \mathrm{~b}$ & $4.53 \mathrm{c}$ & $46.41 \mathrm{~b}$ & $12.28 \mathrm{~b}$ & 116.58 & 21.80 & 563.30 \\
1.00 & 4 & $5.59 \mathrm{a}$ & $5.28 \mathrm{~b}$ & $60.77 \mathrm{a}$ & $15.36 \mathrm{a}$ & 170.90 & 25.80 & 595.35 \\
1.25 & 5 & $6.08 \mathrm{a}$ & $5.68 \mathrm{a}$ & $69.86 \mathrm{a}$ & $16.59 \mathrm{a}$ & 192.59 & 29.80 & 556.71 \\
\hline LSD & - & $* *$ & $* *$ & $* *$ & $* *$ & - & - & - \\
CV(\%) & - & 7.0 & 6.2 & 9.7 & 7.9 & - & - & - \\
\hline
\end{tabular}

ratio over control were 197.81, 175.18 , 120.07 and 59.12 in 2000 and 192.59170 .90 , 116.58 and 56.79 in 2001, respectively. Liberal water supply (1.25 or $1.00 \mathrm{IW/CPE}$ ratio) increased bulb diameter, bulb length and individual bulb weight which resulted increased bulb yield of onion, confirming the results of Singh and Sharma ${ }^{4}$ Hegde ${ }^{5}$ and Palled et al. ${ }^{6}$

Total water use for onion varied from 10.50 to $30.50 \mathrm{~cm}$ in 2000 and 9.80 to $29.80 \mathrm{~cm}$ in 2001. Highest water use efficiency (569.06 $\mathrm{kg} / \mathrm{ha} / \mathrm{cm}$ in 2000 and $595.35 \mathrm{~kg} / \mathrm{ha} \mathrm{cm}$ in 2001) was obtained from soil moisture regimes of $1.25 \mathrm{IW} / \mathrm{CPE}$ ratio which received 6 irrigations giving bulb yield of $15.08 \mathrm{t} / \mathrm{ha}$ in 2000 and $15.36 \mathrm{t} / \mathrm{ha}$ in 2001.

\section{Conclusion}

Soil moisture regime $1.00 \mathrm{IW/CPE}$ ratio (5 irrigations 1, 20, 35, 55 and 70 days after transplanting) was found optimum for onion production in Grey Terrace Soil of Gazipur.

\section{References}

1. A. K. M. Hossain and J. Islam. Status of Allium cepa production in Bangladesh. Hort. Abst. 358 (1994) 33-36.

2. B. B. S. The year Book of Agricultural Statistics of Bangladesh. Statistics Division, Ministry of Plannning. Goverment of the Peoples Republic of Bangladesh (1997).

3. C. S. Pathak. Allium improvement for the tropics: Problem and AVRDC Strategy. Hort. Abst. 358 (1994) 23-93.

4. D. Singh and R. P. Sharma. Effect of soil moisture regimes and nitrogen fertilization on onion. Indian J. of Agronomy. 36(1) (1991) 125-126. 
5. D. M. Hegde. Effect of irrigation and $\mathrm{N}$ fertilization on water relations, canopy temperature, yield. $\mathrm{N}$ uptake and water use of onion. Indian J. Agric. Sci. 56(12) (1986) 858-867.
6. Y. B. Palled, M. D. Kachpur, A. M. Chandrasekharan and A. S. Prabhakar. Response of onion to irrigation and nitrogen. Indian J. Agron. 33(1) (1988) 22-25. 